\title{
Heavy metal bioaccumulation and antioxidative responses in Cardaminopsis arenosa and Plantago lanceolata leaves from metalliferous and non-metalliferous sites: a field study
}

\author{
Aleksandra Nadgórska-Socha • Bartłomiej Ptasiński • \\ Andrzej Kita
}

Accepted: 19 September 2013/Published online: 2 October 2013

(C) The Author(s) 2013. This article is published with open access at Springerlink.com

\begin{abstract}
The purpose of this study was to determine the concentrations of heavy metals (cadmium, lead, zinc, copper, iron and manganese) in soil, their bioavailability and bioaccumulation in plants leaves. This study also examined their influences on the antioxidant response of the plants Cardaminopsis arenosa and Plantago lanceolata grown in metal-contaminated and non-contaminated soils. The activities of guaiacol peroxidase and superoxide dismutase and the levels of antioxidants such as glutathione, proline and non-protein thiols were measured. Concentrations of the examined metals were several to thousands of times lower in the potentially bioavailable fraction than in the acid-extracted fraction of the soil. Similar mode of antioxidant responses in plant leaves of metalliferous populations indicates the tolerance of plants towards heavy metals. However POD and GSHt had a particularly strong role in defense reactions, as their increase was the most common reaction to heavy metal contamination. The levels of $\mathrm{Zn}, \mathrm{Cd}$ and $\mathrm{Pb}$ in the leaves of $C$. arenosa better reflected metal concentrations in the metalliferous and nonmetalliferous soil than the determined metal concentrations in P. lanceolata. Bioaccumulated $\mathrm{Zn}, \mathrm{Cd}$ and $\mathrm{Pb}$ concentrations were above or in the ranges mentioned as toxic for plant tissues and therefore the studied plants have potential for use in phytostabilization.
\end{abstract}

\footnotetext{
A. Nadgórska-Socha $(\bowtie) \cdot$ B. Ptasiński

Department of Ecology, University of Silesia,

Bankowa 9, 40-007 Katowice, Poland

e-mail: aleksandra.nadgorska-socha@us.edu.pl

A. Kita

Analytical Spectroscopy Research Group, Institute of Chemistry,

University of Silesia, Szkolna 7, 40-007 Katowice, Poland
}

Keywords Heavy metals · Antioxidants · Antioxidant enzymes - Cardaminopsis arenosa . Plantago lanceolata
Abbreviations
M Metalliferous
NM Non-metalliferous
POD Guaiacol peroxidase
SOD Superoxide dismutase
GSHt Glutathione total

\section{Introduction}

Heavy metal contamination is a worldwide problem that results in bioaccumulation in the food chains, posing a direct threat to wildlife and human health. Although naturally present in soils, they rarely occur at toxic levels. Heavy metal contamination therefore largely is anthropogenic_-a result of industrial manufacturing, agriculture, combustion of fossil fuels, and road traffic, among other causes (Przedpełska and Wierzbicka 2007; Massa et al. 2010; Serbula et al. 2012). This can be exceptionally high in the vicinity of smelting operations and near mine tailings, which are materials left over after the process of separating the valuable fraction from the uneconomic fraction of an ore (Probst et al. 2009; Bothe 2011).

Environmental quality monitoring using biological material commonly is accepted as a reliable and affordable way to obtain information on heavy metal contamination. The main advantage is the opportunity for long-term comparison without the need for expensive equipment. Such biomonitoring studies include research on metal 
bioaccumulation in vegetation found in contaminated areas, and also for the purpose of finding plants which may be used for phytoremediation (Massa et al. 2010).

Contaminated sites can be considered as reservoirs of native plants with the ability to tolerate or bioaccumulate heavy metals to different ranges. Indigenous plants, very often ruderals, which first colonize disturbed lands, can be valuable bioindicators and bioaccumulators of heavy metals in contaminated areas (Kovács 1992; Massa et al. 2010). Taxa colonizing soils rich in heavy metals are either obligate or facultative metallophytes which have evolved mechanisms to tolerate high concentrations of heavy metals. As such, they are very good biological specimens for research on adaptation to harsh edaphic conditions (Przedpełska and Wierzbicka 2007; Słomka et al. 2008).

We already know several efficient mechanisms for restricting excessive metal concentration in metabolic compartments of plant cells. However, as some metal ions remain in the cytoplasm and induce oxidative stress via the generation of reactive oxygen species (ROS), it is the effectiveness of plants antioxidant defenses that is most crucial for their resistance to metals. Plants have developed scavenging systems that control ROS using non-enzymatic antioxidants, such as glutathione, ascorbate and carotenoids, as well as an enzymatic anti-oxidative system. Activities of anti-oxidative enzymes such as superoxidase dismutase (SOD), glutathione peroxidase (GPX), catalase (CAT) and guaiacol peroxidase (POD), often have been examined in research on heavy metal antioxidant defenses (Pongrac et al. 2009; Kafel et al. 2010; Boojar and Tavakkoli 2011).

This paper examines Plantago lanceolata and Cardaminopsis arenosa (synonym: Arabidopsis arenosa) samples taken from contaminated and non-contaminated sites. P. lanceolata, a member of the Family Plantaginaceae, is a common roadside plant that is widely distributed throughout the world. C. arenosa is a member of the Family Brassicaceae that is very often found in disturbed habitats such as forest edges, road sides, railroad tracks, river banks as well as in grassy and sandy areas. These taxa can also be found among metallophytes occurring in areas contaminated with heavy metals (Przedpełska and Wierzbicka 2007; Gostin 2009; Szarek-Łukaszewska and Grodzińska 2011). Some researchers have highlighted the advantages of studies on such plants growing in natural conditions. The advantage is the direct documentation of microevolutionary processes, i.e., genotype-level adaptation and its plasticity and ecological status (Ernst 2006; Słomka et al. 2008).

In the literature, we find only few reports about $C$. arenosa or P. lanceolata tolerance to heavy metals (SzarekŁukaszewska and Niklińska 2002; Dimitrova and Yurukova 2005; Przedpełska and Wierzbicka 2007; Kurteva 2009; Orłowska et al. 2012). C. arenosa and P. lanceolata were chosen because of their frequent occurrence on metalliferous soils and more frequent occurrence than other metallophytes from study areas on non-metalliferous soil. Among the representatives of Brassicaceae and Plantaginaceae, they are species related to hyperaccumulators, Arabidopsis halleri ( $\mathrm{Zn}, \mathrm{Pb}, \mathrm{Cd}$ hyperaccumulator), Plantago almogravensis (Al hyperaccumulator), and Plantago orbignyana $(\mathrm{Pb}$ accumulator). This is why $C$. arenosa and P. lanceolata may be interesting for studying heavy metal bioaccumulation and ecophysiological response (Przedpełska and Wierzbicka 2007; Braquinho et al. 2007; Bech et al. 2012).

The objective of this study was the comparison of heavy metal $[\mathrm{Cd}, \mathrm{Zn}, \mathrm{Pb}, \mathrm{Mn}, \mathrm{Fe}, \mathrm{Cu}]$ bioaccumulation patterns in leaves of $C$. arenosa and $P$. lanceolata in order to evaluate environmental quality monitoring and environmental risk assessment. The aim of this study was also to examine the activity of selected antioxidant enzymes [superoxidase dismutase (SOD, EC 1.15.1.1), guaiacol peroxidase (POD, EC 1.11.1.7)] and the levels of antioxidants [glutathione, proline and non-protein thiols] in the leaves of $C$. arenosa and $P$. lanceolata, if investigated physiological parameters in $C$. arenosa and $P$. lanceolata plants from the contaminated sites vary from the ones collected at non-contaminated sites. Knowledge about the tolerance of plants to heavy metal toxicity is required before considering their possible application in soil phytostabilization and revegetation of mining areas contaminated with heavy metals. We also studied the potential bioavailability of metals in the soil from contaminated areas and a non-contaminated control area. The following hypothesis was evaluated: heavy metal contamination contributes to changes in the antioxidant responses in both species within the contaminated sites, and in comparison to plants from the noncontaminated area.

\section{Materials and methods}

\section{Study areas}

The study areas are located in the southern part of Poland. We chose four areas contaminated with heavy metals (site code M- metalliferous): (1) vicinity of the zinc plant "Miasteczko Śląskie" (M1), (2) vicinity of a former metal smelting operation "Szopienice" in Katowice (M2), (3) a zinc-lead (calamine) site in Dąbrowa Górnicza (M3), and (4) a calamine waste heap in Bolesław near Olkusz (M4). M3 and M4-calamine areas, were connected with ore mining and processing of zinc ores called calamines. Soil and plant material were also collected from grassland and carpet communities (consisted of species, which tolerate mechanical damages e.g., Lolio-Plantaginetum) on the perimeter of the Pazurek Nature Reserve near Olkusz, 
Table 1 Geographic location and ecological background of the C. arenosa and P. lanceolata investigated natural populations

\begin{tabular}{|c|c|c|c|c|c|}
\hline Name & Habitat & $\begin{array}{l}\text { Origin of } \\
\text { contamination }\end{array}$ & Latitude & Longitude & $\begin{array}{l}\text { Vegetation } \\
\text { (dominant species) }\end{array}$ \\
\hline $\begin{array}{l}\text { Miasteczko Śląskie } \\
\text { (M1) }\end{array}$ & Roadside & $\begin{array}{l}\text { Metallurgic acivity } \\
\text { since } 1967\end{array}$ & $50^{\circ} 31^{\prime} 22.655^{\prime \prime} \mathrm{N}$ & $18^{\circ} 56^{\prime} 8.699^{\prime \prime} \mathrm{E}$ & $\begin{array}{l}\text { Agrostis capillaris } \\
\text { Calamagrostis epigejos } \\
\text { Silene vulgaris } \\
\text { Cardaminopsis arenosa } \\
\text { Melandrium album } \\
\text { Plantago lanceolata }\end{array}$ \\
\hline $\begin{array}{l}\text { Katowice- } \\
\text { Szopienice (M2) }\end{array}$ & Grassland & $\begin{array}{l}\text { Metallurgic acivity } \\
\text { since } 1834\end{array}$ & $50^{\circ} 15^{\prime} 29.65^{\prime \prime} \mathrm{N}$ & $19^{\circ} 6^{\prime} 42.88^{\prime \prime} \mathrm{E}$ & $\begin{array}{l}\text { Agrostis capillaris } \\
\text { Festuca rubra } \\
\text { Silene vulgaris } \\
\text { Cardaminopsis arenosa }\end{array}$ \\
\hline $\begin{array}{l}\text { Dąbrowa Górnicza } \\
\text { (M3) }\end{array}$ & $\begin{array}{l}\text { Forest edge and } \\
\text { grassland }\end{array}$ & $\begin{array}{l}\text { Mining activities } \\
\text { during 19th } \\
\text { century }\end{array}$ & $50^{\circ} 18^{\prime} 58.859^{\prime \prime} \mathrm{N}$ & $19^{\circ} 18^{\prime} 28.62^{\prime \prime} \mathrm{E}$ & $\begin{array}{l}\text { Betula pendula } \\
\text { Festuca ovina } \\
\text { Silene vulgaris } \\
\text { Plantago lanceolata }\end{array}$ \\
\hline Bolesław (M4) & Grassland & $\begin{array}{l}\text { Mining activities } \\
\text { since } 19 \text { th century }\end{array}$ & $50^{\circ} 17^{\prime} 11.472^{\prime \prime} \mathrm{N}$ & $19^{\circ} 28^{\prime} 5.231^{\prime \prime} \mathrm{E}$ & $\begin{array}{l}\text { Silene vulgaris } \\
\text { Cardaminopsis arenosa } \\
\text { Festuca ovina }\end{array}$ \\
\hline Pazurek (NM) & Forest edge & - & $50^{\circ} 19^{\prime} 58.74^{\prime \prime} \mathrm{N}$ & $19^{\circ} 35^{\prime} 59.82^{\prime \prime} \mathrm{E}$ & $\begin{array}{l}\text { Pinus sylvestris } \\
\text { Plantago lanceolata }\end{array}$ \\
\hline
\end{tabular}

selected as a contamination-free control area (Site code "NM"-non-metalliferous). We selected NM site thanks to data from a previous study conducted in the Pazurek Nature Reserve (Nadgórska-Socha unpubl., KandzioraCiupa et al. 2013). The areas studied near smelting operations were situated in the heavily industrialized region of Upper Silesia. The first calamine site (M3) was situated in Silesia and the calamine heap (M4) and control area were located in Małopolska Province. Geographic locations and ecological backgrounds of the investigated natural populations of $C$. arenosa and $P$. lanceolata are presented in Table 1. The Pazurek Nature Reserve perimeter, selected as a control area, is located nearby the contaminated sites (66 km from M1; $46 \mathrm{~km}$ from M2, $25 \mathrm{~km}$ from M3 and $15 \mathrm{~km}$ from M4) and was selected because of similar climatic conditions to the other study areas. Soil $\mathrm{pH}$ was lower than in metalliferous sites because of the pine forest in the vicinity. It was also used as control due to low zinc and cadmium concentrations and $\mathrm{Pb}$ concentration much lower than in the contaminated sites. Also, $\mathrm{N}$ and organic matter content were similar, especially to M3 and M4 sites (Table 1).

\section{Soil and plant material}

We sampled the plant material and soil in early June 2009. The soil samples were taken from topsoil $(0-15 \mathrm{~cm}$ in depth), as heavy metal contamination mainly was concentrated in the topsoil and the roots of the selected plants do not grow any deeper. Each sampling site covered $100 \mathrm{~m}^{2}$ within which leaf and soil samples were randomly collected. Ten (10) soil sub-samples and 20 individual plants of each species-(C. arenosa and $P$. lanceolata $)$ were taken from each sampling area and pooled into one sample of each species per site. The plants were taken during the flowering stage, the highest metabolic point during the plant life cycle (Dazy et al. 2008). After collection plants samples were placed in plastic bags, deposited in ice, immediately transported to the laboratory and then frozen at $-80{ }^{\circ} \mathrm{C}$ until analysis. The heavy metal content determinations and biochemical analyses were conducted on the leaves of the plants. Each analysis was performed in five replicates.

Analysis of metal concentration in soil and plant samples

The concentrations of cadmium, lead, zinc, copper, iron and manganese were analyzed. The metal content of the soil was estimated according to the method by Bouwman et al. (2001) and Ostrowska et al. (1991), and previously described in details (Nadgórska-Socha et al. 2013). Metals were extracted from air-dried samples of soil using $0.01 \mathrm{M}$ $\mathrm{CaCl}_{2}$ (potentially bioavailable elements) or using $2 \mathrm{M}$ $\mathrm{HNO}_{3}$ (extracted elements). Soil $\mathrm{pH}$ was measured using a 1:2.5 soil to water ratio. Organic matter content (expressed 
in \%) was measured following the methods of Ostrowska et al. (1991). The levels of C, N, and S were measured with a CNS analyzer (Variomax CNS, Elementar Analysensysteme GmbH, Germany).

In order to determine heavy metal concentrations, plant material was washed in tap and distilled water and dried at $105{ }^{\circ} \mathrm{C}$. After wet mineralization [previously described in detail (Nadgórska-Socha et al. 2013)], metal contents (Cd, $\mathrm{Pb}, \mathrm{Zn}, \mathrm{Cu}, \mathrm{Fe}$ and $\mathrm{Mn}$ ) were measured by inductively coupled plasma emission spectroscopy (Spektroflame-M spectrophotometer, ICP Spectro Analytical Instruments, Germany). The quality of the analytical procedure was checked using a reference material (Certified Reference Material CTA-OTL-1 Oriental Tobacco Leaves, Department of Analytical Chemistry, Institute of Nuclear Chemistry and Technology, Poland) with the same quantities as samples.

Analysis of the biochemical parameters of the plants

Crushed plant parts were homogenized in a $100 \mathrm{mM}$ phosphate buffer ( $\mathrm{pH}$ 6.8) for the analysis of POD activity (1:7 ratio) and centrifuged at $12,000 \times g$ for $20 \mathrm{~min}$. The entire procedure was carried out at $4{ }^{\circ} \mathrm{C}$. The activity of POD was measured at $470 \mathrm{~nm}$ according to Fang and Kao (2000) using guaiacol as the substrate, and it was expressed in $\mu \mathrm{mol}$ of tetra-guaiacol per $\min ^{-1}$ per $\mathrm{mg}$ of protein $^{-1}$.

The analysis of superoxide dismutase (SOD) was performed in a buffer with $3 \mathrm{mM} \mathrm{MgSO} 4,1 \mathrm{mM}$ dithiotreitol (DTT), $3 \mathrm{~mm}$ EDTA (1:5 ratio) and centrifuged at $12,000 \times g$ for $20 \mathrm{~min}$. The entire procedure was carried out at $4{ }^{\circ} \mathrm{C}$. The reaction was measured spectrophotometrically at $560 \mathrm{~nm}$ according to Beauchamp and Fridovich (1971). One unit of SOD was defined as the amount of enzyme activity that was able to inhibit by $50 \%$ the photoreduction of nitroblue tetrazolium (NBT) to blue formazan (Beauchamp and Fridovich 1971). This method was chosen because the method was supposed to be suitable and it is still being used (sometimes with modifications) in recent ecophysiological studies.

To measure the contents of non-protein thiols, plant material was homogenized in a $5 \mathrm{vol} / \mathrm{g}$ mixture containing 5-sulphosalicylic acid ( $2 \mathrm{~g}$ per $100 \mathrm{~mL}$ ), and $1 \mathrm{mM}$ EDTA and sodium ascorbate $(0.15 \mathrm{~g}$ per $100 \mathrm{~mL})$. The number of non-protein $\mathrm{SH}$ groups was established based on a curve prepared using L-cysteine and expressed as nmol- $\mathrm{SH} \mathrm{g}^{-1}$ fresh weight (Mass et al. 1987).

The acid-ninhydrin method was used to determine proline content (Bates et al. 1973). Plant material was homogenized in sulfosalicylic acid ( $3 \mathrm{~g}$ per $100 \mathrm{~mL}$ ). The proline content expressed in $\mu$ mol proline $\mathrm{g}^{-1}$ fresh weight was calculated as described by Bates et al. (1973).
The content of total glutathione (GSHt) was measured following the methods of Anderson (1985), and protein content was measured following the methods of Bradford (1976), using the appropriate standard curves of oxidized glutathione and bovine standard albumin solutions, respectively.

To detect the glutathione concentration, plant leaves were homogenized in TCA (trichloroacetic acid, $5 \mathrm{~g}$ per $100 \mathrm{~mL}$ ) and $0.125 \mathrm{mM}$ phosphate buffer $(\mathrm{pH}$ 6.3) with $6.3 \mathrm{mM}$ EDTA, and then were centrifuged at $10,000 \times g$ for $10 \mathrm{~min}$ at $4{ }^{\circ} \mathrm{C}$. The linear changes in the absorbance of the reaction mixtures were measured at $412 \mathrm{~nm}$ and GSHt was expressed as $\mu \mathrm{mol}$ GSH $\mathrm{g}^{-1}$ fresh weight.

Statistical assessment

The biochemical parameter data and metal content were checked for normality and equality of variance, and when necessary the data was log transformed. One-way ANOVA was carried out to compare the difference of means from various sampling sites and significant statistical differences were established using Tukey's test, $p<0.05$ [ANOVA; Statistica version 10 package, StatSoft, Inc. (2011)]. We also calculated the linear correlation coefficient between the metal concentrations in separate soil extractants and in the leaves of plants, as well as between the metal concentrations and biochemical parameters in the leaves of $C$. arenosa and P. lanceolata.

CANOCO 4.5 was used to carry out Principal Component Analysis (PCA) (Ter Braak and Šmilauer 2002). Principal Component Analysis assessed the similarities and relations between biochemical parameters and elemental content in the plants.

\section{Results}

The bioavailability of metals in soil

There was a clear difference between the concentration of metals in the fraction of soil extracted with $\mathrm{HNO}_{3}$ and the fraction of soil extracted with $\mathrm{CaCl}_{2}$ (Table 2). The highest concentration of $\mathrm{Zn}$ was found in the acid extracted fraction of soil. The highest acid extracted concentrations of $\mathrm{Cd}$ (301.2 $\left.\mathrm{mg} \mathrm{kg}^{-1}\right), \quad \mathrm{Zn}\left(70,445.8 \mathrm{mg} \mathrm{kg}^{-1}\right)$ and $\mathrm{Cu}$ (74.1 $\left.\mathrm{mg} \mathrm{kg}^{-1}\right)$, Fe $(2,632.5)$ were in the soil collected in M3 site, while $\mathrm{Pb}\left(4,230.9 \mathrm{mg} \mathrm{kg}^{-1}\right)$ concentration was the highest in M4 site.

Metal concentrations were from 8 times ( $\mathrm{Cd}$ in $\mathrm{M} 2)$ to about 3,200 times ( $\mathrm{Zn}$ in M3) lower in the bioavailable fraction $\left(\mathrm{CaCl}_{2}\right.$ extraction) in metalliferous sites. Potentially available $\mathrm{Cd}$ ranged from 0.76 to $21 \%$ of $\mathrm{Cd}$ extracted with $\mathrm{HNO}_{3}$ (Table 2), and thus proved to be the 
Table 2 The concentrations of selected metals in fractions of the soils extracted with $\mathrm{HNO}_{3}$ and $\mathrm{CaCl}_{2}\left[\mathrm{mg} \mathrm{kg}^{-1}\right]$, organic matter content [\%], N, C, S [\%] and $\mathrm{pH}$ value from investigated sites

The different letters denote significant differences between the particular metal concentrations in the fraction extracted with $\mathrm{HNO}_{3}$, extracted with $\mathrm{CaCl}_{2}$, organic matter contents and $\mathrm{pH}$ values $(p<0.05)$

\begin{tabular}{lrrrrr}
\hline Metal/stand & \multicolumn{1}{c}{ M1 } & \multicolumn{1}{c}{ M2 } & M4 & NM \\
\hline $\mathrm{Cd}\left(\mathrm{HNO}_{3}\right)$ & $6.1 \mathrm{a}$ & $90.8 \mathrm{~b}$ & $301.2 \mathrm{~d}$ & $175.6 \mathrm{c}$ & $2.7 \mathrm{e}$ \\
$\mathrm{Zn}\left(\mathrm{HNO}_{3}\right)$ & $2,878.3 \mathrm{a}$ & $8,403.3 \mathrm{~b}$ & $70,445.8 \mathrm{c}$ & $68,570.8 \mathrm{c}$ & $358.8 \mathrm{~d}$ \\
$\mathrm{~Pb}\left(\mathrm{HNO}_{3}\right)$ & $959.1 \mathrm{a}$ & $394.7 \mathrm{~b}$ & $3,619.1 \mathrm{~d}$ & $4,230.9 \mathrm{c}$ & $123.1 \mathrm{e}$ \\
$\mathrm{Cu}\left(\mathrm{HNO}_{3}\right)$ & $11.2 \mathrm{a}$ & $34.3 \mathrm{~b}$ & $74.1 \mathrm{~d}$ & $8.5 \mathrm{c}$ & $12.9 \mathrm{a}$ \\
$\mathrm{Mn}\left(\mathrm{HNO}_{3}\right)$ & $65.7 \mathrm{a}$ & $236.7 \mathrm{~b}$ & $768.0 \mathrm{c}$ & $779.2 \mathrm{c}$ & $64.7 \mathrm{a}$ \\
$\mathrm{Fe}\left(\mathrm{HNO}_{3}\right)$ & $1,273.9 \mathrm{a}$ & $1,740.8 \mathrm{~b}$ & $2,632.5 \mathrm{~d}$ & $2,027.0 \mathrm{c}$ & $1,380.3 \mathrm{e}$ \\
$\mathrm{Cd}\left(\mathrm{CaCl}_{2}\right)$ & $0.2 \mathrm{a}$ & $11.2 \mathrm{~b}$ & $2.3 \mathrm{~d}$ & $1.2 \mathrm{c}$ & $0.6 \mathrm{a}$ \\
$\mathrm{Mn}\left(\mathrm{CaCl}_{2}\right)$ & $5.1 \mathrm{a}$ & $2.3 \mathrm{~b}$ & $3.1 \mathrm{~d}$ & $2.1 \mathrm{c}$ & $1.7 \mathrm{e}$ \\
$\mathrm{Zn}\left(\mathrm{CaCl}_{2}\right)$ & $32.4 \mathrm{a}$ & $374.0 \mathrm{~b}$ & $22.0 \mathrm{c}$ & $34.8 \mathrm{a}$ & $11.5 \mathrm{~d}$ \\
$\mathrm{Organic} \mathrm{matter} \mathrm{content}$ & $2.1 \mathrm{a}$ & $3.1 \mathrm{a}$ & $12.0 \mathrm{~b}$ & $14.0 \mathrm{~b}$ & $11.9 \mathrm{~b}$ \\
$\mathrm{pH}$ & $7.5 \mathrm{a}$ & $7.3 \mathrm{~b}$ & $7.4 \mathrm{a}$ & $7.3 \mathrm{~b}$ & $5.6 \mathrm{c}$ \\
$\mathrm{N}$ & $0.1 \mathrm{a}$ & $0.1 \mathrm{a}$ & $0.3 \mathrm{~b}$ & $0.4 \mathrm{c}$ & $0.3 \mathrm{~b}$ \\
$\mathrm{C}$ & $1.1 \mathrm{a}$ & $1.5 \mathrm{~b}$ & $8.8 \mathrm{c}$ & $11.3 \mathrm{~d}$ & $4.4 \mathrm{e}$ \\
$\mathrm{S}$ & $0.03 \mathrm{a}$ & $0.07 \mathrm{~b}$ & $0.02 \mathrm{c}$ & $0.03 \mathrm{a}$ & $0.04 \mathrm{~d}$ \\
\hline
\end{tabular}

most bioavailable element. The bioavailable $\mathrm{Mn}$ ranged from 0.3 to $7.7 \%$ and bioavailable $\mathrm{Zn}$ from 0.03 to $4.5 \%$ of the total amount extracted with $\mathrm{HNO}_{3}$.

The concentrations of other metals were under the detectable limit of the apparatus. The examined soil from all areas had rather low organic matter and $\mathrm{C}$ content, especially in the vicinity of contamination emitters. $\mathrm{N}$ content in soil of M3 and M4 sites was similar to NM area (Table 2). The $\mathrm{pH}$ values were above 7 at the contaminated sites and $\mathrm{pH}$ was in the acidic range only in the control area (NM) (Table 2).

Heavy metal concentration in plants

The mean values of heavy metal concentrations in leaves of investigated plants were found in the following descending order- $\mathrm{Zn}>\mathrm{Fe}>\mathrm{Pb}>\mathrm{Mn} \geq \mathrm{Cd}>\mathrm{Cu}$. C. arenosa bioaccumulated higher amounts of $\mathrm{Zn}, \mathrm{Cd}, \mathrm{Pb}, \mathrm{Mn}$ in the leaves than $P$. lanceolata. Bioaccumulated amounts of $\mathrm{Fe}$ (except M3) and $\mathrm{Cu}$ were similar in the leaves of these two species (Tables 3,4).

The highest $\mathrm{Zn}$ concentration $\left(5,438.6 \mathrm{mg} \mathrm{kg}^{-1}\right)$ was found in C. arenosa leaves collected in M2 site, the highest $\mathrm{Pb}$ content $\left(256.55 \mathrm{mg} \mathrm{kg}^{-1}\right)$ in $\mathrm{M} 1$ site and the highest $\mathrm{Cd}$ content $\left(100.15 \mathrm{mg} \mathrm{kg}^{-1}\right)$ in M4. Fe $\left(2,588.3 \mathrm{mg} \mathrm{kg}^{-1}\right)$ and $\mathrm{Mn}\left(74.3 \mathrm{mg} \mathrm{kg}^{-1}\right)$ content were the highest in the M3 area (Tables 3, 4)

We noted a strong positive correlation between concentrations of $\mathrm{Zn}$ (correlation coefficient $=0.81$ ) and $\mathrm{Mn}$ (correlation coefficient $=0.92$ ) examined under $\mathrm{CaCl}_{2}$ extraction and in the leaves of $C$. arenosa. We also found a positive correlation between concentrations of Mn (correlation coefficient $=0.48$ ) and $\mathrm{Fe}$ (correlation coefficient $=0.72$ ) under $\mathrm{HNO}_{3}$ extraction and in the leaves of $P$. lanceolata. The range of other correlation coefficients was statistically insignificant.
Table 3 The concentrations of heavy metals ( $\mathrm{mg} \mathrm{kg}^{-1}$ d.w.) in the leaves of $C$. arenosa

\begin{tabular}{lrrrrr}
\hline $\begin{array}{l}\text { Stand } \\
\text { metal }\end{array}$ & \multicolumn{1}{l}{ M1 2 M3 } & \multicolumn{1}{l}{ M4 } & \multicolumn{1}{l}{ NM } \\
\hline $\mathrm{Cd}$ & $45.6 \mathrm{a}$ & $41.5 \mathrm{a}$ & $12.9 \mathrm{c}$ & $100.2 \mathrm{~b}$ & $1.4 \mathrm{~d}$ \\
$\mathrm{~Pb}$ & $256.6 \mathrm{a}$ & $30.8 \mathrm{~b}$ & $94.5 \mathrm{~d}$ & $70.8 \mathrm{c}$ & $6.2 \mathrm{e}$ \\
$\mathrm{Zn}$ & $3,054.1 \mathrm{a}$ & $5,438.7 \mathrm{~b}$ & $2,828.0 \mathrm{ac}$ & $2,594.9 \mathrm{c}$ & $256.9 \mathrm{~d}$ \\
$\mathrm{Cu}$ & $4.8 \mathrm{a}$ & $2.3 \mathrm{~b}$ & $3.9 \mathrm{~d}$ & $0.8 \mathrm{c}$ & $2.2 \mathrm{~b}$ \\
$\mathrm{Fe}$ & $274.1 \mathrm{a}$ & $365.7 \mathrm{~b}$ & $2,588.3 \mathrm{~d}$ & $170.5 \mathrm{c}$ & $279.8 \mathrm{a}$ \\
$\mathrm{Mn}$ & $62.3 \mathrm{a}$ & $12.9 \mathrm{~b}$ & $74.3 \mathrm{c}$ & $11.8 \mathrm{~b}$ & $23.8 \mathrm{~d}$
\end{tabular}

The different letters denote significant differences between the metal concentration in plants from metalliferous and non-metalliferous populations $(p<0.05)$

Table 4 The concentrations of heavy metals $\left(\mathrm{mg} \mathrm{kg}^{-1}\right.$ d.w.) in the leaves of $P$. lanceolata

\begin{tabular}{lrrrrr}
\hline Metal/stand & \multicolumn{1}{c}{ M1 } & \multicolumn{1}{c}{ M2 } & \multicolumn{1}{c}{ M3 } & \multicolumn{1}{c}{ M4 } \\
\hline $\mathrm{Cd}$ & $13.8 \mathrm{a}$ & $9.1 \mathrm{~b}$ & $5.7 \mathrm{~b}$ & $7.1 \mathrm{~b}$ & $1.0 \mathrm{c}$ \\
$\mathrm{Pb}$ & $107.2 \mathrm{a}$ & $121.3 \mathrm{~b}$ & $67.5 \mathrm{~d}$ & $19.5 \mathrm{c}$ & $0.03 \mathrm{e}$ \\
$\mathrm{Zn}$ & $372.9 \mathrm{a}$ & $209.8 \mathrm{~b}$ & $420.1 \mathrm{a}$ & $219.1 \mathrm{~b}$ & $101.3 \mathrm{c}$ \\
$\mathrm{Cu}$ & $6.2 \mathrm{a}$ & $3.5 \mathrm{a}$ & $1.2 \mathrm{~b}$ & $4.1 \mathrm{a}$ & $3.2 \mathrm{c}$ \\
$\mathrm{Fe}$ & $232.7 \mathrm{a}$ & $208.2 \mathrm{a}$ & $1,065.6 \mathrm{~b}$ & $175.7 \mathrm{a}$ & $218.7 \mathrm{a}$ \\
$\mathrm{Mn}$ & $13.5 \mathrm{a}$ & $7.0 \mathrm{~b}$ & $22.7 \mathrm{c}$ & $9.5 \mathrm{a}$ & $6.1 \mathrm{~b}$ \\
\hline
\end{tabular}

The different letters denote significant differences between the metal concentration in plants from metalliferous and non-metalliferous populations $(p<0.05)$

The biochemical status of the plants

An increase in GSHt level was found in leaves of $C$. arenosa and $P$. lanceolata collected from the most contaminated areas in comparison to its content in plants from the (NM) area. Only in the leaves of $P$. lanceolata from M1 
site and in the leaves of C. arenosa from M3 was the GSHt content comparable to the level in the leaves of this species from the NM area.

The highest GSHt concentration $\left(198 \mu \mathrm{mol} \mathrm{GSH} \mathrm{g}^{-1}\right.$ fresh weight) was recorded in the leaves of $C$. arenosa (M4), about two times more than in the plants from the NM area (Fig. 1). The total glutathione pool positively correlated with $\mathrm{Zn}$ and $\mathrm{Cd}$ content in $C$. arenosa leaves and with $\mathrm{Pb}$ contentin $P$. lanceolata leaves. In addition, a negative correlation was found between $\mathrm{Fe}, \mathrm{Mn}, \mathrm{Cu}$ content and glutathione concentration in $C$. arenosa leaves (Tables 5, 6).

An opposite tendency was recorded for non-protein thiols. Their levels were mostly lower in the leaves of plants that were exposed to metal contamination compared with the NM area (with the exception of $P$. lanceolata in M1 site) (Fig. 2), ranging from 137 to 311 and $248-578 \mathrm{nmol}^{-} \mathrm{SH} \mathrm{g}^{-1}$ fresh weight in C. arenosa and $P$. lanceolata respectively (Fig. 2). Non-protein thiol concentration in $P$. lanceolata leaves positively correlated with $\mathrm{Cu}$ and $\mathrm{Pb}$ contents, in opposition to a negative relationship between $\mathrm{Cd}$ or $\mathrm{Fe}$ contents and non-protein thiols levels in $C$. arenosa leaves (Tables 5, 6). We detected a decrease of proline concentration in the leaves of $P$. lanceolata in contaminated areas in comparison with the non-contaminated areas. However, we detected an

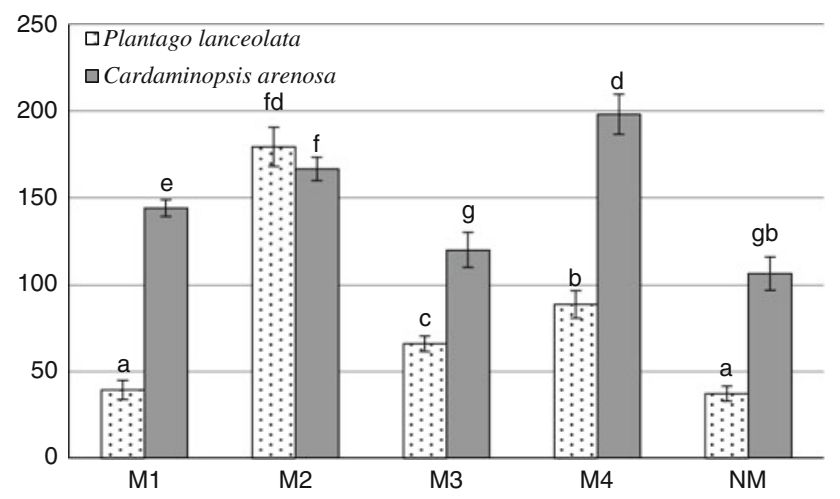

Fig. 1 GSHt content in P. lanceolata and C. arenosa leaves

Table 5 The correlation coefficients between metal concentration and antioxidant measurements in the leaves of Cardaminopsis arenosa plants $(p<0.05)$

\begin{tabular}{llllll}
\hline & PRO & GSHt & SH & SOD & POD \\
\hline $\mathrm{Cd}$ & 0.52 & 0.92 & -0.58 & NS & -0.42 \\
$\mathrm{Zn}$ & $\mathrm{NS}$ & 0.51 & $\mathrm{NS}$ & $\mathrm{NS}$ & 0.40 \\
$\mathrm{~Pb}$ & 0.43 & $\mathrm{NS}$ & $\mathrm{NS}$ & $\mathrm{NS}$ & $\mathrm{NS}$ \\
$\mathrm{Cu}$ & -0.10 & -0.51 & $\mathrm{NS}$ & 0.50 & 0.68 \\
$\mathrm{Fe}$ & -0.79 & -0.42 & -0.46 & 0.95 & 0.76 \\
$\mathrm{Mn}$ & -0.27 & -0.52 & NS & 0.85 & 0.74 \\
\hline
\end{tabular}

NS not significant
Table 6 The correlation coefficients between metal concentration and antioxidant measurements in the leaves of Plantago lanceolata plants $(p<0.05)$

\begin{tabular}{llllll}
\hline & PRO & GSHt & SH & SOD & POD \\
\hline $\mathrm{Cd}$ & -0.59 & NS & NS & NS & 0.73 \\
$\mathrm{Zn}$ & -0.74 & NS & NS & NS & 0.41 \\
$\mathrm{~Pb}$ & -0.45 & 0.53 & 0.51 & NS & 0.86 \\
$\mathrm{Cu}$ & $\mathrm{NS}$ & $\mathrm{NS}$ & 0.61 & -0.67 & 0.59 \\
$\mathrm{Mn}$ & -0.53 & $\mathrm{NS}$ & $\mathrm{NS}$ & 0.76 & $\mathrm{NS}$ \\
$\mathrm{Fe}$ & $\mathrm{NS}$ & $\mathrm{NS}$ & $\mathrm{NS}$ & 0.80 & -0.46 \\
\hline
\end{tabular}

NS not significant

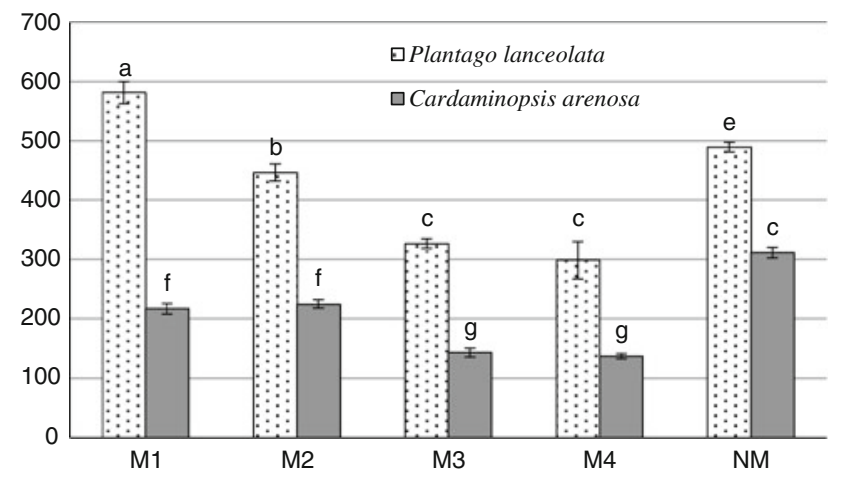

Fig. 2 Non-protein -SH group content in P. lanceolata and $C$. arenosa leaves

increasing tendency in $50 \%$ of cases for $C$. arenosa in contaminated areas (Fig. 3). The proline content negatively correlated with $\mathrm{Fe}, \mathrm{Mn} \mathrm{Cu}$ concentrations in the leaves of $C$. arenosa plants and with $\mathrm{Cd}, \mathrm{Zn}, \mathrm{Pb}$ and $\mathrm{Mn}$ in the leaves of $P$. lanceolata (Tables 5, 6).

The activities of POD were higher in most cases in plants exposed to heavy metals in soil than in those from the NM area. Only in the C. arenosa leaves from M4 site and $P$. lanceolata leaves from M3 site was the POD activity comparable with the activity in plant leaves from the NM area. The activity of POD ranged from 356 to $852 \mu \mathrm{mol}$ tetra-guaiacol $\mathrm{min}^{-1} \mathrm{mg}$ protein ${ }^{-1}$ in leaves of C. arenosa and 198-670 $\mu \mathrm{mol}$ tetra-guaiacol $\mathrm{min}^{-1} \mathrm{mg}$ protein $^{-1}$ in P. lanceolata (Fig. 4).

Superoxide dismutase activity was higher in the case of C. arenosa leaves collected at the M3 site (Fig. 5) than SOD activity in plant leaves at the NM site. We obtained similar results for $P$. lanceolata, with a higher SOD activity in the leaves of this plant collected at M3 and M4 sites than in plants from the NM area (Fig. 5).

Superoxide dismutase activity positively correlated with the $\mathrm{Fe}$ and $\mathrm{Mn}$ concentrations in the leaves of both species, and with $\mathrm{Cu}$ in $C$. arenosa leaves (Tables 5, 6). A negative correlation was found between the $\mathrm{Cu}$ concentration and SOD activity in $P$. lanceolata leaves (Table 6). 


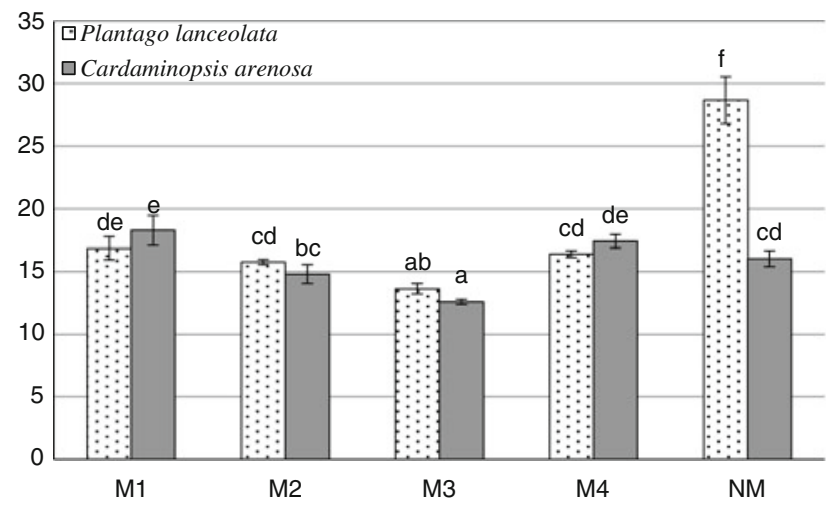

Fig. 3 Proline content in P. lanceolata and C. arenosa leaves

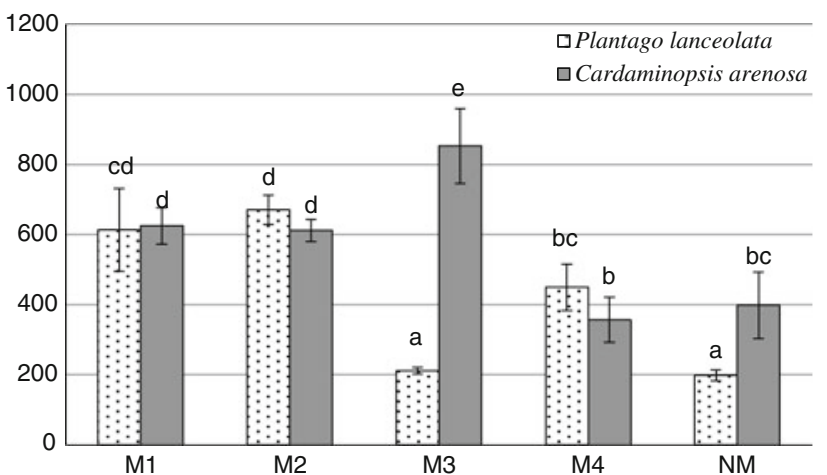

Fig. 4 POD activity in P. lanceolata and C. arenosa leaves

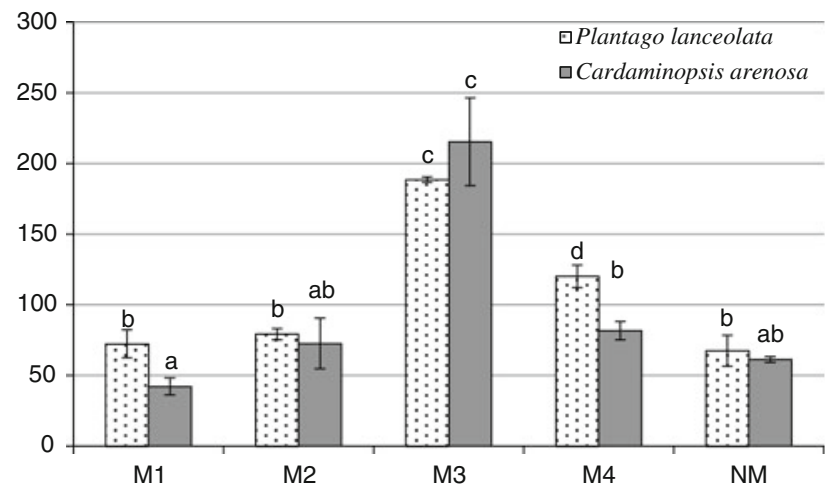

Fig. 5 SOD activity in $P$. lanceolata and $C$. arenosa leaves

In $C$. arenosa, the first two axes of PCA explained $99.5 \%$ of physiological characteristic variability $(75 \%$ by axis $1 ; 24.5 \%$ by axis 2) (Fig. 6). Similarly, in $P$. lanceolata, the first two axes of PCA explained $97.8 \%$ of physiological characteristic variability $(77.8 \%$ by axis 1 , $20.0 \%$ by axis 2) (Fig. 7).

In $C$. arenosa, the left side of the diagram in Fig. 6 presents samples collected in most of the contaminated areas. Also identified is a strong association between SOD and $\mathrm{Fe}, \mathrm{Cd}$ and $\mathrm{GSH}, \mathrm{Pb}$ and $\mathrm{Zn}$. In the case of $P$. lanceolata at contaminated sites, there was a strong

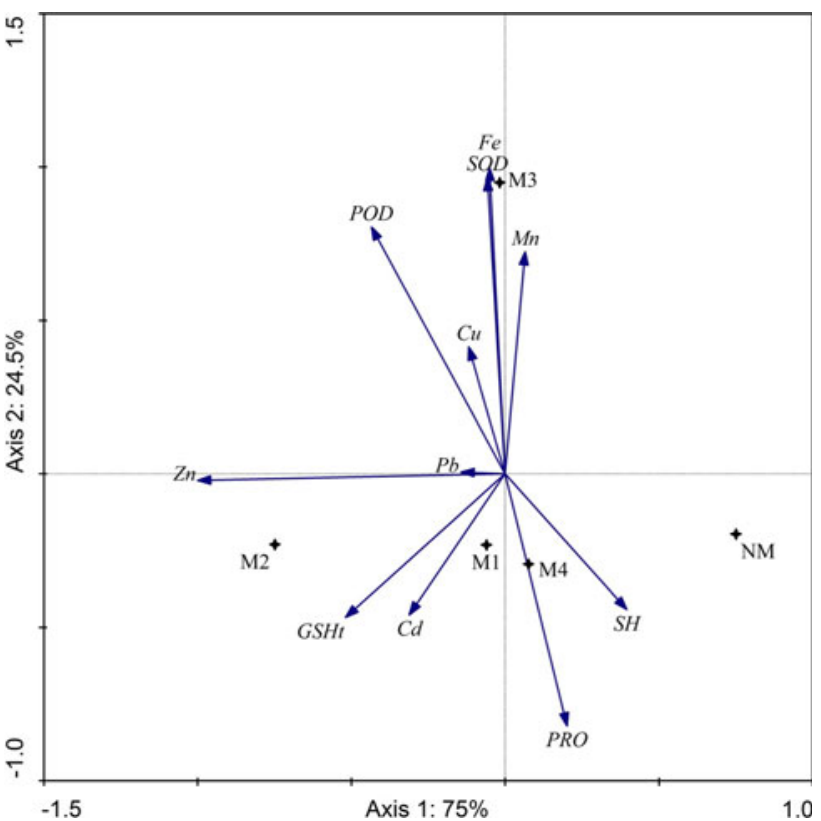

Fig. 6 Principal component analysis performed on $C$. arenosa biochemical parameters and elements contents in the plants on investigated areas

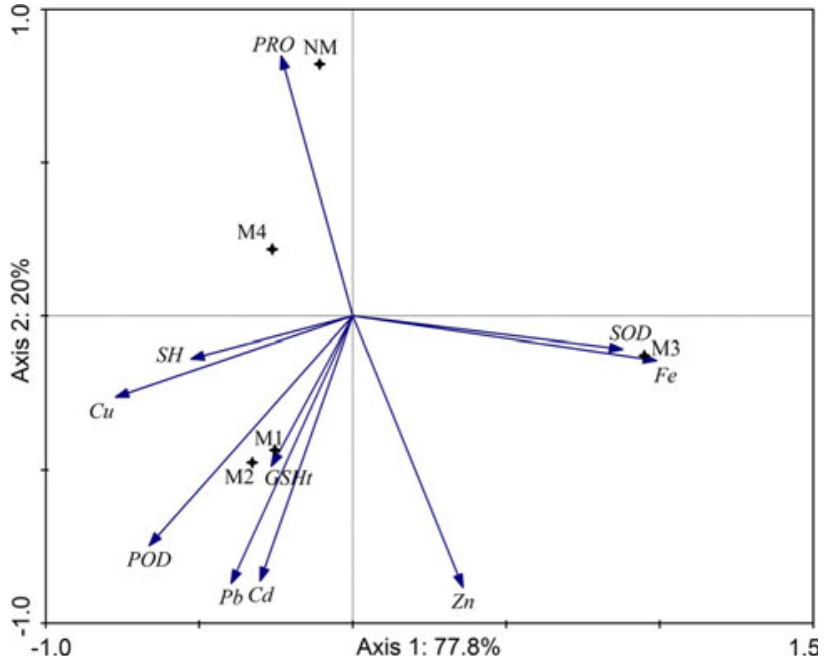

Fig. 7 Principal component analysis performed on $P$. lanceolata biochemical parameters and elements contents in the plants on investigated areas

relationship between POD and GSHt, $\mathrm{Pb}$ and $\mathrm{Cd}, \mathrm{SOD}$ and $\mathrm{Fe}$, and between non-protein - $\mathrm{SH}$ groups and $\mathrm{Cu}$.

\section{Discussion}

In this study we were interested in evaluating the physiological characteristics of heavy metal bioaccumulation capacity in two metallophytes, $C$. arenosa and P. lanceolata, growing in contaminated and non-contaminated areas. 
Previously, Bidar et al. (2007) and Słomka et al. (2008) emphasized that many experiments are conducted on cultivated plants in laboratory conditions. Our results provide information about anti-oxidative defense in common plants, such as ruderals, widespread on metalliferous soil$C$. arenosa and P. lanceolata. We also assessed heavy metal bioavailability in contaminated areas in comparison to a non-contaminated area.

The soil-plant transfer of chemical elements is part of nature's element cycling. Total concentration of elements in soil cannot be considered as a good indicator of bioavailability. Bioavailable metals estimation allows the assessment of a plant's potential to mobilize or bioaccumulate metals from soils (Braquinho et al. 2007). There is extensive literature concerning heavy metal contamination and exchangeable metal content or potential bioavailability in soil in the vicinity of smelting operations, dumps and mining areas (Liu et al. 2004; Chojnacka et al. 2005; Menzies et al. 2007). In our study, a higher concentration of (acid extracted) examined metals was found in calamine areas (M3 and M4) in comparison to the vicinity of the contamination emitters- $\mathrm{M} 1$ and $\mathrm{M} 2 . \mathrm{Cd}$ and $\mathrm{Zn}$ were the most abundant among the examined metals. The bioavailable concentrations of $\mathrm{Cd}, \mathrm{Zn}$ and $\mathrm{Mn}$ were higher in metalliferous soil near the smelting operation (M1 and M2) than in soil near the mining area (M3 and M4). In a study by Majewska et al. (2011) on soil from a $\mathrm{Zn}-\mathrm{Pb}$ waste heap in Bolesław, following $0.1 \mathrm{M} \mathrm{NaNO}_{3}$ extraction, the bioavailable concentration of $\mathrm{Zn}$ and $\mathrm{Cd}$ was less than $0.5 \%$. In our study, bioavailability results for the calamine sites (M3 and M4) were similar to Majewska et al. (2011) for Cd but lower for $\mathrm{Zn}$ (1.6-2.4 times). The bioavailability of these metals in soil near the smelting operations M1 and M2 was higher in our study and ranged from 1.1 to $12.4 \%$ of metal amounts that were acid extracted. In addition, Moreno-Jiménez et al. (2009) emphasized that Cd and Zn usually are more mobile in soil than $\mathrm{Cu}$. In their study, the percentages of extractable metals in relation to total soil metals showed that $\mathrm{Cd}$ and $\mathrm{Mn}$ were significantly more extractable than other metals in soils surrounding an abandoned mine in NW Madrid, Spain. In addition, Lei et al. (2010) showed that the proportions of water-soluble and exchangeable fractions extracted by selected analytical methods were the lowest among all gathered fractions in garden and paddy soils from a $\mathrm{Pb} / \mathrm{Zn}$ mining area, similar to the results obtained by Banásowá et al. (2006) in former mining regions in central Slovakia.

Metal-tolerant plant species (metallophytes) maintain good performance as they are able to cope with higher internal metal levels due to adaptive genetic changes. However, successful colonization of highly metal enriched soils demands a de novo and in situ evolution of metal tolerance (Ernst 2006). In this study, examined specimens of $C$. arenosa and P. lanceolata came from metalliferous and non-metalliferous populations. Among metallophytes, pseudometallophytes, such as the species mentioned above, are attractive models for studying phenotypic differentiation driven by natural selection. In highly contaminated sites extreme environmental conditions may promote rapid differentiation between metalliferous and non-metalliferous populations (Meyer et al. 2010).

Herein, we compare the obtained results of metal bioaccumulation in the leaves of the examined species with the results of field studies on various plant species and their bioaccumulation abilities. The aim was to show the significance of information obtained directly from the environment not only in the bioindication of contamination but also in the potential use of individual plant species in phytomanagement of metal-contaminated soil. Bech et al. (2012) emphasizes that metal contaminated areas are potential sources of contamination due to wind and water erosion. Efforts to restore a vegetation cover can benefit stabilization and contamination control, and improve aesthetical aspects.

Gjorgieva et al. (2011) evaluated different plant organs from Urtica doica, Taraxacum officinale, Matricaria recutita and Robinia pseudoacacia as possible bioindicators of heavy metal contamination in the Republic of Macedonia. T. officinale, $U$. dioica and $R$. pseudoacacia were the highest accumulators. The maximum $\mathrm{Pb}$ content (in $R$. pseudoacacia) was $174.52 \mathrm{mg} \mathrm{kg}^{-1}$ in the Veles area where $\mathrm{Pb}$ and $\mathrm{Zn}$ metallurgical activity were present, whereas maximum $\mathrm{Zn}$ concentration for $U$. dioica leaves sampled near a lead smelting plant was $465 \mathrm{mg} \mathrm{kg}^{-1}$. These bioaccumulation levels are similar to the amounts of $\mathrm{Zn}$ and $\mathrm{Pb}$ recorded for the leaves of $P$. lanceolata sampled in a contaminated area in our study.

Moreno-Jiménez et al. (2009) investigated heavy metal transference to wild flora at an abandoned mine site in NW Madrid, Spain. The ranges of bioaccumulated heavy metals $\left(\mathrm{mg} \mathrm{kg}^{-1}\right)$ in annual and perennial herb shoots were $1.28-14.51 \mathrm{mg} \mathrm{kg}^{-1}$ for $\mathrm{Cd}, 59.18-581.1 \mathrm{mg} \mathrm{kg}^{-1}$ for $\mathrm{Zn}$, $2.77-23.5 \mathrm{mg} \mathrm{kg}^{-1}$ for $\mathrm{Cu}, 46.5-230.2 \mathrm{mg} \mathrm{kg}^{-1}$ for $\mathrm{Mn}$, $39.5-422.1 \mathrm{mg} \mathrm{kg}^{-1}$ for Fe. The bioaccumulation ranges were similar to heavy metal bioaccumulation results in our study, especially for $P$. lanceolata leaves. In this study, $\mathrm{Cd}$ and $\mathrm{Zn}$ were higher in $C$. arenosa in contaminated areas. However, the results of both our and Moreno-Jiménez et al. (2009) investigations correspond with the statement that in metalliferous soils there are gradients of plant-available metal levels which are reflected in the gradient of metal tolerant individuals (Ernst 2006).

Majewska et al. (2011) examined above-ground parts of Biscutella laevigata from the Bolesław heaps and determined 4,581 $\mathrm{mg} \mathrm{kg}^{-1} \mathrm{Zn}, 447 \mathrm{mg} \mathrm{kg}^{-1} \mathrm{~Pb}$ and $58 \mathrm{mg} \mathrm{kg}^{-1}$ $\mathrm{Cd}$. Similar amounts of $\mathrm{Cd}$ but lower $\mathrm{Pb}$ and $\mathrm{Zn}$ 
concentrations were found in a higher bioaccumulating plant-C.arenosa-in our investigations. Szarek-Łukaszewska and Niklińska (2002) reported that in plants growing on calamine dumps near Olkusz, maximum metal concentrations in roots and shoots of $B$. laevigata were $14.3 \mathrm{mg} \mathrm{kg}^{-1} \mathrm{Cd}, 111 \mathrm{mg} \mathrm{kg}^{-1} \mathrm{~Pb}$ and $410 \mathrm{mg} \mathrm{kg}^{-1} \mathrm{Zn}$. $P$. lanceolata contained up to $65.6 \mathrm{mg} \mathrm{kg}^{-1} \mathrm{Cd}, 157 \mathrm{mg} \mathrm{kg}^{-1}$ $\mathrm{Pb}$ and 2,540 $\mathrm{mg} \mathrm{kg}^{-1} \mathrm{Zn}$. Dimitrova and Yurukova (2005), after research on $P$. lanceolata in contaminated (vicinity of non-ferrous smelting works) and from sites away from major sources of contamination, emphasized that $P$. lanceolata leaves can be used as bioaccumulative indicators not only for $\mathrm{Zn}$ and $\mathrm{Pb}$ but also $\mathrm{Cd}$. However, in our study the leaves of $C$. arenosa were better bioaccumulative indicators for these metals. In our investigations, $C$. arenosa better reflected soil heavy metal concentrations. Also Kucharski et al. (2005) described $C$. arenosa bioaccumulating properties. In a mesocosm experiment with highly metal contaminated soil from a non-ferrous mine and metal smelting site in southern Poland, and soil with calcium phosphate as a heavy metal-stabilizing amendment, Deschampsia caespitosa and $C$. arenosa were examined (Kucharski et al. 2005). C. arenosa was found undesirable for phytostabilization as it bioaccumulated high amounts of $\mathrm{Zn}$ and $\mathrm{Cd}$ in its shoots even though it provided better growth cover than $D$. caespitosa in soil without metal stabilizing amendment (Kucharski et al. 2005).

To evaluate environmental risk assessment, the obtained concentrations in the leaves of examined specimens were compared with metal concentrations mentioned as toxic for plant tissues. In our investigation, the measured concentrations of $\mathrm{Cd}$ and $\mathrm{Zn}$ in $C$. arenosa leaves generally were above toxic ranges in the metalliferous populations (Tables 2,7). $\mathrm{Pb}$ contents in $C$. arenosa leaves, and $\mathrm{Cd}, \mathrm{Zn}$ and $\mathrm{Pb}$ concentrations in P. lanceolata leaves, were in the ranges mentioned as toxic for plant tissues (Tables 2, 3, 7). $\mathrm{Cd}$ concentrations in the leaves of $C$. arenosa from M4 site were in the cut-off range of contents mentioned for hyperaccumulators (Tables 2, 7). The $\mathrm{Cd}$ and $\mathrm{Zn}$ bioaccumulation efficiency in $C$. arenosa, a plant with higher bioaccumulation, was also compared with the accumulation capacity of hyperaccumulators. In comparison to hyperaccumulators only plants from the metalliferous $C$. arenosa population at the M2 site bioaccumulated $50 \%$ of the $\mathrm{Zn}$ amount bioaccumulated by hyperaccumulators (Alloway and Ayres 1999; Kabata-Pendias 2001; Serbula et al. 2012). However, Nouri et al. (2009) suggested that metal concentrations higher than toxic level in some species indicate that internal detoxification metal tolerance mechanisms might also exist, and therefore plant utility for phytoremediation is possible. Our results for the species studied also confirm this statement. Additionally, Yoon et al. (2006) and Massa et al. (2010) postulated that the
Table 7 Heavy metals concentration previously reported as toxic for plants, cut-off of heavy metals concentration used to define plant hyperaccumulators in comparison to heavy metals allowable concentration in soil (in $\mathrm{mg} \bullet \mathrm{kg}^{-1}$ )

\begin{tabular}{llll}
\hline & $\begin{array}{l}\text { Toxic concentration } \\
\text { in plants }\end{array}$ & $\begin{array}{l}\text { Hyperaccumulation } \\
\text { limits }^{\mathrm{a}}\end{array}$ & $\begin{array}{l}\text { Allowable } \\
\text { Concentration }^{\text {in soil }}\end{array}$ \\
\hline $\mathrm{Cd}$ & $5-30$ & 100 & 4 \\
$\mathrm{Zn}$ & $100-400$ & 10,000 & 300 \\
$\mathrm{~Pb}$ & $30-300$ & 1,000 & 100 \\
$\mathrm{Cu}$ & $20-100$ & 1,000 & 150 \\
$\mathrm{Mn}$ & $400-1,000$ & 10,000 & - \\
$\mathrm{Fe}$ & - & 10,000 & - \\
\hline
\end{tabular}

\footnotetext{
${ }^{a}$ Massa et al. (2010)

b The regulation of Environment Minister about the standards of soil and ground quality (2002)

${ }^{c}$ Kabata-Pendias (2001)
}

identification of metal-tolerant plant species from natural vegetation in field sites and vegetational characterisation in contaminated sites, is relevant under an ecological point of view and even more when considering the plant species as accumulators in phytoremediation plans. As emphasized by Gonzáles et al. (2006) and Bech et al. (2012) metal concentrations in wild plants may vary. Tolerant species are able to grow in highly contaminated substrates, some of them behave as excluders and store the excessive levels of trace elements that may enter their roots, thereby protecting the more sensitive tissues from toxicity. Previously published data show that $P$. lanceolata is an excluder species (Szarek-Łukaszewska and Niklińska 2002). However, further investigations, also under controlled conditions, are needed to confirm if the studied species are indeed excluders (Gonzáles et al. 2006). In addition, phytostabilization requires metal tolerant species that are efficient in both rapid coverage of the contaminated soil and exclusion of metals from plant parts that are consumed by herbivores (Bech et al. 2012).

In our study, we also compared the anti-oxidative response in examined plant species that are widespread in contaminated areas. Information on the changes in the activity of oxidative enzymes obtained from field studies may be helpful for using them as biomarkers in the future and also may help better understand the defense mechanisms of plants experiencing chronic heavy metal stress and for research connected with revegetation of heavy metal contaminated sites. We proved that GSHt was increased in most investigated individuals of $C$. arenosa and $P$. lanceolata in metalliferous areas. GSH participates in the control of $\mathrm{H}_{2} \mathrm{O}_{2}$ levels in plant cells (Foyer and Noctor 2005), and plays a fundamental role in many cellular detoxification processes of xenobiotics and heavy metals. GSH does this by prior activation and conjugation 
with such compounds. Next to quenching of ROS during metal exposure, GSH acts as a precursor for the synthesis of phytochelatins (PCs) (Yadav 2010). Hawrylak and Szymańska (2004) described reduced glutathione as the most abundant non-protein thiol; however, in plant cells, other low-molecular weight compounds containing - $\mathrm{SH}$ groups can exist, such as PCs (phytochelatins), MTs (metallothioneins), thionins and defensins. Molecules containing sulfur, which exist in a wide variety in cells, may fulfill different functions and may be independently regulated (Mishra et al. 2009). In our study GSHt was positively related with $\mathrm{Zn}$ and $\mathrm{Cd}$ concentration in C.arenosa and with $\mathrm{Pb}$ concentration in $P$. lanceolata (Tables 5, 6; Figs. 6, 7). Conversely, the $-\mathrm{SH}$ group content was lower in most cases of investigated plants in metalliferous areas. In our previous field study on Philadelphus coronarius collected from contaminated areas, an increase of glutathione was found in leaves not infested with aphids in contaminated areas, and similar to this study the content of $-\mathrm{SH}$ groups was lower or was at a comparable level in comparison to non-contaminated areas (Kafel et al. 2010). Additionally, Boojar and Tavakkoli (2011) described that a pioneer plant species, Zygophyllum fabago, in comparison to Peganum harmala, grown in tailings of a $\mathrm{Pb}$ and $\mathrm{Zn}$ mine, showed an increase of PCs and GSH levels in aerial parts. Pongrac et al. (2009) found that $\mathrm{Cd}$ amendment decreased total chlorophyll concentration and glutathione reductase activity but increased non-protein thiol concentration in less tolerant Thlaspi praeox in comparison to $T$. caerulescens.

Our present study found a lower proline concentration in leaves of $P$. lanceolata in contaminated area. However, we also found a comparable proline level in most cases of metalliferous $C$. arenosa populations. Proline accumulation in plants is reported during conditions of drought, high salinity, high light and UV irradiation, elevated heavy metal levels, oxidative stress and in response generally to biotic stresses. Proline has been shown to function as a molecular chaperone able to protect protein integrity and enhance the activities of different enzymes (Szabados and Savouré 2009). In many studies, an increase in proline in plants has been recorded during response to heavy metal stress (Sharma and Dietz 2006; Sun et al. 2007). An increase in free proline in environmental contamination was also found in Philadelphus coronarius (Kafel et al. 2010). On the other hand, in metallophytes like Silene vulgaris, constitutive proline content was higher in metaltolerant ecotypes, whereas metal-induced proline accumulation was higher in a non-tolerant ecotype (Schat et al. 1997). An investigation of proline in Brassica juncea showed an elevated level at lower concentrations of $\mathrm{Cd}$ and $\mathrm{Pb}$ but at higher concentrations it decreased (John et al. 2009).
The antioxidant enzymes, especially SOD, CAT and POD are present in various cellular compartments, functioning at different steps of ROS degradation and removal (Mishra et al. 2006). It is known that SOD is the main antioxidant enzyme functioning as a superoxide radical scavenger in living organisms, a first line defender against oxidative stress caused by ROS. POD, in addition to CAT and ascorbate peroxidase (APX), is an enzyme involved in the removal of $\mathrm{H}_{2} \mathrm{O}_{2}$ (Słomka et al. 2008; Boojar and Tavakkoli 2011). The balance maintenance between ROS and the antioxidant system is crucial for survival and adaptation of plants which grown in soils with relatively constant level of heavy metals (Słomka et al. 2008). Research on activity of the antioxidant enzymes is important to better understand antioxidant protection, especially in metallophytes.

In our study a higher POD activity in most cases for $C$. arenosa and $P$. lanceolata was recorded on metalliferous sites as compared to non-metalliferous ones. Additionally, the POD activity positively correlated with the concentration of $\mathrm{Cu}, \mathrm{Fe}$ and $\mathrm{Mn}$ in $C$. arenosa and with $\mathrm{Pb}, \mathrm{Cd}$, $\mathrm{Zn}$ and $\mathrm{Cu}$ in $P$. lanceolata leaves (Tables 5, 6; Figs. 6, 7). The resistance of plants to heavy metal stress may be associated with the decreased susceptibility of enzymes to metal inhibition (Liu et al. 2004). This statement was confirmed for POD activity. Higher SOD activity was found only in leaves of the studied plants on calamine sites-M3 (for both) and M4 (for P. lanceolata). An increase in SOD activity in leaves of both studied species was observed under influence of Fe and Mn (Tables 5, 6; Figs. 6,7). Elevated SOD and POD activities in the leaves and roots of barley along with bioaccumulation of $\mathrm{Al}, \mathrm{Cd}$ and $\mathrm{Cu}$ were observed by Guo et al. (2007). An elevation of POD activity in $P$. coronarius leaves was found by Kafel et al. 2010. Boojar and Tavakkoli (2011) describe the elevation of SOD in aerial parts of $Z$. fabago in a metalcontaminated area (Zone1) as well as a comparable level of SOD activity of another species, P. harmala. Five species, including Arrhenaterum eliatus, Bromus tectorum, Euphorbia cyparissias, Hypericum perforatum and Tanacetum vulgare were examined by Dazy et al. (2009) in an ecotoxicological study of contaminated wasteland communities at a former coke factory in France. A clear dose-effect relationship was observed for SOD activity for all these species, POD presented bell-shaped dose-response curves. In a similar study on Erigerion canadensis, Matricaria recutita and Oenothera biennis in a contaminated area (also a former coke factory), SOD and POD activity exhibited higher levels in E. canadensis and $M$. recutita in contaminated areas compared to control (Dazy et al. 2008). In the leaves of Viola tricolor from one of the metalliferous areas of the Warpie heap in Chrzanów (southern Poland), SOD activity was higher than in other 
metalliferous and non-contaminated sites. Comparable or lower activity was characteristic for POD in the leaves of $V$. tricolor in metalliferous versus non-contaminated areas of Zakopane meadows (Słomka et al. 2008). The investigators emphasized that chronic metal-induced stress evokes a very similar mode of anti-oxidative response in all representatives of the populations and did not cause a measurable increase in oxidative stress. Differences in enzyme activity were the results of adjustment of the plants to different conditions (Słomka et al. 2008). In our study, a similar mode of antioxidant responses has been observed in plant leaves of metalliferous populations. This indicates the tolerance of these plants to heavy metals. However, POD and GSHt had a particularly strong role of in defense reactions, as their increase was the most common reaction to heavy metal contamination. Our main hypothesis was confirmed only for parameters such as POD and GSHt.

\section{Conclusion}

Cardaminopsis arenosa (L.) Hayek and P. lanceolata L. have been used as model organisms and as examples of metallophytes because of their common presence throughout the studied areas. The levels of metals, especially $\mathrm{Zn}, \mathrm{Cd}$ and $\mathrm{Pb}$ in the leaves of $C$. arenosa better reflected the metal concentrations in metalliferous and nonmetalliferous soil than did the levels of metals in $P$. lanceolata leaves. The evaluated Cd concentration in the leaves of $C$. arenosa from the M4 site were in the range of heavy metal content suggested for hyperaccumulators. In metalliferous soils, there are gradients of bioavailable metal concentrations which are mirrored in varied metal tolerant individuals. We found several examples of high correlations between antioxidant parameters and concentrations of metals in soil and leaves of plants, and higher POD activity as well as GSHt content. POD and GSHt had a particularly strong role in heavy metal defense reactions. These relationships are characteristic of other field studies involving metallophytes. Generally, proline and thiol concentrations in plants in metalliferous areas were not elevated in relation to non-metalliferous areas. In conclusion, our results indicate that the ruderals $C$. arenosa (L.) Hayek and $P$. lanceolata L. may play an integral role in contaminated area stabilization and protection against heavy metal movement.

Acknowledgments This work was financially supported by grant for Young Scientist at the Biology and Environmental Protection Department, University of Silesia.

Conflict of interest The authors declare that they have no conflict of interest.
Open Access This article is distributed under the terms of the Creative Commons Attribution License which permits any use, distribution, and reproduction in any medium, provided the original author(s) and the source are credited.

\section{References}

Alloway BJ, Ayres DC (1999) Heavy metals. In: chemical basis of environment air pollution, PWN, Warszawa, pp 218-246 (in Polish)

Anderson ME (1985) Determination of glutathione and glutathione disulfide in biological samples. Methods Enzymol 113:548-555

Banásowá V, Horak O, Čiamporova M, Nadubinská M, Lichtschildl I (2006) The vegetation of metalliferous and non-metalliferous grasslands in two former mine regions in central Slovakia. Biol Bratislava 61:433-439

Bates L, Waldren R, Teare D (1973) Rapid determination of free proline for water-stress studies. Plant Soil 39:205-207

Beauchamp C, Fridovich I (1971) Superoxide dismutase: improved assays and an assay applicable to acrylamide gels. Anal Biochem 44:276-287

Bech J, Duran P, Roca N, Poma W, Sánchez I, Roca-Pérez L, Boluda R, Barceló J, Poschenrieder Ch (2012) Accumulation of $\mathrm{Pb}$ and $\mathrm{Zn}$ in Bidens triplinervia and Senecio sp. Spontaneous species from mine spoils in Peru and their potential use in phytoremediation. J Geochem Explor 123:109-113

Bidar G, Garçon G, Pruvot C, Dewaele D, Cazier F, Douay F, Shirali P (2007) Behavior of Trifolium repens and Lolium perenne growing in a heavy metal contaminated field: plant metal concentration and phytotoxicity. Environ Pollut 147:546-553

Boojar MMA, Tavakkoli Z (2011) Antioxidative responses and metal accumulation in invasive plant species growing on mine tailings in Zanjan, Iran. Pedosphere 21:802-812

Bothe H (2011) Plants in heavy metal soils. In: Sherameti I, Varma A (eds) Detoxification of heavy metals, soil biology 30. SpringerVerlag, Berlin Heidelberg, pp 35-56

Bouwman L, Bloem J, Römkens P, Boon G, Vangronsveld J (2001) Beneficial effects of the growth of metal tolerant grass on biological and chemical parameters in copper and zinc contaminated sandy soils. Minerva Biotechnol 13:19-26

Bradford M (1976) A rapid and sensitive method for the quantitation of microgram quantities of protein utilizing the principle of protein dye binding. Anal Biochem 44:276-287

Braquinho C, Serrano H, Pinto M, Martins-Loução M (2007) Revisiting the plant hyperaccumulation criteria to rare plants and earth abundant elements. Environ Pollut 146:437-443

Chojnacka K, Chojnacki AH, Górecka H, Górecki H (2005) Bioavailability of heavy metals from polluted soils to plants. Sci Total Environ 337:175-182

Dazy M, Jung V, Férard J-F, Masfaraud J-F (2008) Ecological recovery of vegetation on a coke-factory soil: role of plant antioxidant enzymes and possible implications in site restoration. Chemosphere 74:57-63

Dazy M, Béraud E, Cotelle S, Grévilliot F, Férard J-F, Masfaraud J-F (2009) Changes in plant communities along soil pollution gradients: responses of leaf antioxidant enzyme activities and phytochemlatin contents. Chemosphere 77:376-383

Dimitrova I, Yurukova L (2005) Bioindication of anthropogenic pollution with Plantago lanceolata (Plantaginaceae): metal accumulation, morphological and stomatal leaf characteristics. Phytol Balcan 11:89-96

Ernst WHO (2006) Evolution of metal tolerance in higher plants. For Snow Landsc Res 80:251-274 
Fang WC, Kao C (2000) Enhanced peroxidase activity in rice leaves in response to excess iron, copper and zinc. Plant Sci 158:71-76

Foyer CH, Noctor G (2005) Redox homeostasis and antioxidant signaling a metabolic link between stress perception and physiological responses. Plant Cell 17:1866-1875

Gjorgieva D, Kadifkova-Panovska T, Bačeva K, Stafilov T (2011) Assesment of heavy metals pollution in Republic of Macedonia using a plant assay. Arch Environ Contam Toxicol 60:233-240

Gostin IN (2009) Structural modification induced by air pollutants in Plantago lanceolata leaves. Analelle Univeritãtiidin Oradea, Fascicula Biologie, XVI/I:61-65

Guo TR, Zhang GP, Zhang YH (2007) Physiological changes in barley plants under combined toxicity of aluminium, copper and cadmium. Colloids Surf B 57:182-188

Hawrylak B, Szymańska M (2004) Selenium as a sulphydrylic group inductor in plants. Cell Mol Biol Lett 9:329-336

John R, Ahmad P, Gadgil K, Sharma S (2009) Heavy metal toxicity: effect on plant growth, biochemical parameters and metal accumulation by Brassica juncea L. Int J Plant Prod 3:65-75

Kabata-Pendias A (2001) Trace elements in soils and plants, 3rd edn. CRC press, Boca Raton FL

Kafel A, Nadgórska-Socha A, Gospodarek J, Babczyńska A, Skowronek M, Kandziora M, Rozpendek K (2010) The effects of Aphis fabae infestation on the antioxidant response and heavy metal content in field grown Philadelphus coronarius plants. Sci Total Environ 408:1111-1119

Kandziora-Ciupa M, Ciepał R, Nadgórska-Socha A, Barczyk G (2013) A comparative study of heavy metal accumulation and antioxidant responses in Vaccinium myrtillus L. leaves in polluted and non-polluted area. Environ Sci Pollut Res 20:4920-4932

Kovács M (ed) (1992) Biological indicators in environmental protection. Ellis Horwood, New York

Kucharski R, Sas-Nowosielska A, Małkowski E, Japenga J, Kuperberg JM, Pogrzeba M, Krzyżak J (2005) The use of indigenous plant species and calcium phosphate for stabilization of highly metal polluted sites in southern Poland. Plant Soil 273:291-305

Kurteva MK (2009) Comparative study on Plantago major and $P$. lanceolata (Plantaginaceae) as bioindicators of the pollution in the region of the Asarel Copper Dressing Works. Phytol Balcan 15:261-271

Lei M, Zhang Y, Khan S, Qin PF, Liao BH (2010) Pollution, fractionation, and mobility of $\mathrm{Pb}, \mathrm{Cd}, \mathrm{Cu}$, and $\mathrm{Zn}$ in garden and paddy soils from $\mathrm{Pb} / \mathrm{Zn}$ mining area. Environ Monit Assess 168:215-222

Liu J, Xing ZT, Li TY, Huang H (2004) Bioaccumulation and ecophysiological responses to copper stress in two populations of Rumex dentatus L. from copper contaminated and non-contaminated sites. Environ Exp Bot 52:43-51

Majewska M, Kurek E, Słomka A (2011) Effect of plant growth on total concentrations of $\mathrm{Zn}, \mathrm{Pb}$, and $\mathrm{Cd}$, and their distribution between operational fractions in the upper layer of 100-year-old zinc-lead waste heap. Pol J Environ Stud 20:591-597

Mass F, De Kok L, Peters J, Kuiper PA (1987) Comparative study on the effects of $\mathrm{H}_{2} \mathrm{~S}$ and $\mathrm{SO}_{2}$ fumigation on the growth and accumulation of sulfate and sulfhydryl compounds in Trifolium pratense L., Glycine max Merr., Phaseolus vulgaris L. J Exp Bot 38:1459-1469

Massa N, Andreucci F, Poli M, Aceto M, Barbato M, Berta G (2010) Screening for heavy metal accumulators amongst autochtonous plants in a polluted site in Italy. Ecotoxicol Environ Saf 73:1988-1997

Menzies NW, Donn MJ, Kopittked PM (2007) Evaluation of extractants for estimation of the phytoavailable trace metals in soils. Environ Pollut 145:121-130
Meyer C-L, Kostecka AA, Saumitou-Laprade P, Créach A, Castric V (2010) Variability of zinc tolerance among and within populations of the pseudometallophyte species Arabidopsis halleri and possible role of directional selection. New Phytol 185:130-142

Mishra S, Srivastava S, Tripathi RD, Govindarajan R, Kuriakose SV, Prasad MNV (2006) Phytochelatin synthesis and response of antioxidants during cadmium stress in Bacopa monnieri L. Plant Physiol Biochem 44:25-37

Mishra S, Tripathi RD, Srivastava S, Dwivedi S, Trivedi PK, Dhankher OP, Khare A (2009) Thiol metabolism play significant role during cadmium detoxification by Ceratophyllum demersum L. Bioresour Technol 100:2155-2161

Moreno-Jiménez E, Peňalosa JM, Manzano R, Carpena-Ruiz RO, Gamarra R, Esteban E (2009) Heavy metals distribution in soils surrounding an abandoned mine in NW Madrid (Spain) and their transference to wild flora. J Hazard Mater 162:854-859

Nadgórska-Socha A, Kafel A, Kandziora-Ciupa M, Gospodarek J, Zawisza-Raszka A (2013) Accumulation of heavy metals and antioxidant responses in Vicia faba plants grown on monometallic contaminated soil. Environ Sci Pollut Res 20:1124-1134

Nouri J, Khorasani N, Lorestani B, Karami M, Hassani H, Yousefi N (2009) Accumulation of heavy metals in soil and uptake by plants species with phytoremediation potential. Environ Earth Sci 59:315-323

Orłowska E, Godzik B, Turnau K (2012) Effect of different arbuscular mycorhizal fungal isolates on growth and arsenic accumulation in Plantago lanceolata L. Environ Pollut 168:121-130

Ostrowska A, Gawliński S, Szczubiałka Z (1991) In: method of analysis and estimate soil and plants property, Catalogue of the Environmental Protection Institute Warsaw pp 334-336 (in Polish)

Pongrac P, Zhao FJ, Razinger J, Zrimec A, Regvar M (2009) Physiological responses to $\mathrm{Cd}$ and $\mathrm{Zn}$ in two $\mathrm{Cd} / \mathrm{Zn}$ hyperaccumulating Thlaspi species. Environ Exp Bot 66:479-486

Probst A, Liu H, Fanjul M, Liao B, Hollande E (2009) Response of Vicia faba L. to metal toxicity on mine tailing substrate: geochemical and morphological changes in leaf and root. Environ Exp Bot 66:297-308

Przedpełska E, Wierzbicka M (2007) Arabidopsis arenosa (Brassicaceae) from a lead-zinc waste heap in southern Poland-a plant with high tolerance to heavy metals. Plant Soil 299:43-53

Regulation by the Minister of Environment dated 9 September 2002. Official Gazette No. 165, Pos. 1359th. (in Polish)

Schat H, Sharma SS, Vooijs R (1997) Heavy metal-induced accumulation of free proline in a metal-tolerant and a nontolerant ecotype of Silene vulgaris. Physiol Plant 101:477-482

Serbula SM, Milljkovic DDJ, Kovacevic RM, Ilic AA (2012) Assessment of airborne heavy metal pollution using plant parts and topsoil. Ecotoxicol Environ Saf 76:209-214

Sharma SS, Dietz KJ (2006) The significance of amino acids and amino acid-derived molecules in plant responses and adaptation to heavy metal stress. J Exp Bot 57:711-726

Słomka A, Libik-Konieczny M, Kuta E, Miszalski Z (2008) Metalliferous and non-metalliferous populations of Viola tricolor represent similar mode of antioxidative response. J Plant Physiol 165:1610-1619

StatSoft, Inc. (2011). STATISTICA (data analysis software system), version 10. www.statsoft.com

Sun RL, Zhou QZ, Sun FH, Jin CX (2007) Antioxidative defense and proline/phytochelatin accumulationin a newly discovered Cd-hyperaccumulator, Solanum nigrum L. Environ Exp Bot 60:468-476

Szabados L, Savouré A (2009) Proline: a multifunctional aminoacid. Trends Plant Sci 15:89-97

Szarek-Łukaszewska G, Grodzińska K (2011) Grasslands of Zn-Pb post-mining area (Olkusz ore-bearing region, S Poland). Pol Bot J 56:245-260 
Szarek-Lukaszewska G, Niklińska M (2002) Concentration of alkaline and heavy metals in Biscutella laevigata L. and Plantago lanceolata $\mathrm{L}$. growing on calamine spoils (S. Poland). Acta Biol Cracov Bot 44:29-38

Ter Braak CJF, Šmilauer P (2002) CANOCO Reference manual and user's guide to Canoco for Windows: software for canonical community ordination (version 4.5), Microcomputer Power (Ithaca, NY, USA)
Yadav SK (2010) Heavy metals toxicity in plants: an overview on the role of glutathione and phytochelatins in heavy metal stress tolerance of plants. S Afr J Bot 76:167-179

Yoon J, Cao X, Zhou Q, Ma LQ (2006) Accumulation of Pb, Cu, and $\mathrm{Zn}$ in native plants growing on contaminated Florida site. Sci Total Environ 368:456-464 